\title{
TOKMÁNYBA FOGOTT FÚRÓSZÁR SZABAD REZGÉSEINEK MÉRÉSE LÉZER DOPPLER MÓDSZERREL
}

\author{
Béres Miklós \\ mérnöktanár, Miskolci Egyetem, Fizikai és Elektrotechnikai Intézet \\ 3515 Miskolc, Miskolc-Egyetemváros, e-mail: mechbere@uni-miskolc.hu \\ Jenyó Tamás \\ villamosmérnök, Miskolci Egyetem, Fizikai és Elektrotechnikai Intézet \\ 3515 Miskolc, Miskolc-Egyetemváros, e-mail: fizjetam@uni-miskolc.hu \\ Paripás Béla \\ egyetemi tanár, Miskolci Egyetem, Fizikai és Elektrotechnikai Intézet \\ 3515 Miskolc, Miskolc-Egyetemváros, e-mail: fizpari@uni-miskolc.hu
}

\begin{abstract}
Absztrakt
Lézer Doppler interferométerrel (LDV) tokmányba fogott és megpenditett fúrószárak keresztirányú rezgéseit tanulmányoztuk. Megállapitottuk, hogy a szabad rezgéseket általában két közeli (néhány \%-on belüli) frekvenciájú komponens szuperpoziciójából származó lebegés dominálja, amelyek a fúrószárak horonyvég irányú és az arra meröleges, keresztirányú rezgéséhez tartoznak. A hangvilla modell a $9 \mathrm{~mm}$ átméröjü fúrószár szabad rezgéseinek frekvenciáit pár százalékon belüli pontossággal megadja, a vastagabb (10 és 12mm-es) fúrószárak esetében viszont 15-20\%-kal felülbecsli. Vizsgáltuk a fúróvég megtámasztásának, a fúrószár tokmányból kintebb húzásának és a koppintás típusának (tompa vagy éles) hatását is a rezgési spektrumra.
\end{abstract}

Kulcsszavak: Lézer Doppler rezgésmérés, fúrószár rezgések, Fourier-analizis

\begin{abstract}
The transverse vibrations of drill bits held in a chuck and plucked were studied using a laser Doppler interferometer $(L D V)$. We found that free vibrations are generally dominated by a beat originating from the superposition of two components with similar frequencies (within a few percent), which belong to the transverse vibrations of the drill bits in the direction of the groove end and perpendicular to that. The tuning fork model gives the frequencies of the free vibrations of the $9 \mathrm{~mm}$ diameter drill bit with an accuracy of a few percent, while in the case of thicker $(10$ and $12 \mathrm{~mm})$ drill bits it overestimates by 15 20 percent. We also examined the effect of supporting the drill bit, pulling the drill bit further out of the chuck, and the type of tapping (blunt or sharp) on the vibration spectrum.
\end{abstract}

Keywords: Laser Doppler vibrometry, drill bit vibrations, Fourier analysis

\section{Bevezetés}

A Miskolci Egyetem Fizikai Tanszékén lévő lézer Doppler elven működő LDV (Laser Doppler Vibrometer) interferométer készüléket már évek óta használjuk a mérnöki gyakorlatban felmerülő különböző rezgési problémák tanulmányozására. Ezek között előkelő helyen szerepel a gépipari fúrások közben fellépő rezgések vizsgálata, amely témában több publikációnk is megjelent (M. Béres \& Paripás, 2018; 
Miklós Béres \& Paripás, 2017b, 2018). A kapott rezgési képek és spektrumok igen összetettek, elemzésük nehéz feladat. Ehhez segítség lehet a már tokmányba fogott, de még fúrást nem végző fúrószárak rezgéseinek pontos ismerete. Jelen munkánkkal ezt a hiányt kívánjuk pótolni.

\section{Mérési módszer}

Az LDV készülék lézersugarát a vizsgálni kívánt objektum felületének adott pontjára kell fókuszálni, melynek rezgési sebességének amplitúdójára és frekvenciájára lehet következtetni a visszavert lézerfény frekvenciája segítségével, a Doppler-effektus alapján. A Doppler-effektus lényegét fejezi ki az (1) öszszefüggés, mely szerint, ha egy hullámforrás és egy megfigyelő egymáshoz képest elmozdul, akkor a megfigyelő a hullámot más frekvenciájúnak érzékeli. Ez az effektus képezi a sebességmérés alapját. Az akusztikai Doppler effektusnál a közeghez képest a megfigyelő és a hullámforrás is mozoghat $v_{m}$, illetve $v_{f}$ sebességgel. A $v$ sebességgel közeledő tárgy esetén visszaverő hullám detektálásakor a következő összefüggés érvényes:

$$
f=f_{0} \frac{c+v}{c-v}
$$

Az LDV egy két (He-Ne) lézersugaras Mach-Zehnder interferométer, ami méri a frekvencia különbséget a belső referencia nyaláb és a mérősugár között. A céltárgyról szóródott fényt először összegyüjtjük, majd a fénydetektoron interferáltatjuk a referencia sugárral. A két lézersugár között alap esetben is $\mathrm{f}_{\mathrm{B}}=20 \mathrm{MHz}$ eltolás van, amit egy Bragg-cella hoz létre. Ennek segítségével tudjuk a mechanikai rezgéseknek megfelelő (alacsony) frekvenciákat detektálni, továbbá a sebesség irányítását azonosítani (Béres és Paripás, 2017a). A 2. ábrán látható a vibrométer vázlatos felépítése. A referencia frekvenciát $\mathrm{f}_{0}$, a Bragg frekvenciát $\mathrm{f}_{\mathrm{B}}$, a Doppler eltolódást pedig $\mathrm{f}_{\mathrm{D}}$ jelöli. Végeredményül a (3) összefüggést kapjuk.

$$
\begin{gathered}
f=f_{0} \frac{c+v}{c-v} @ f_{0}\left(1+2 \frac{v}{c}\right)=f_{0}+f_{D} \\
f_{D}=2 f_{0} \frac{v}{c}=2 \frac{v}{\lambda}
\end{gathered}
$$

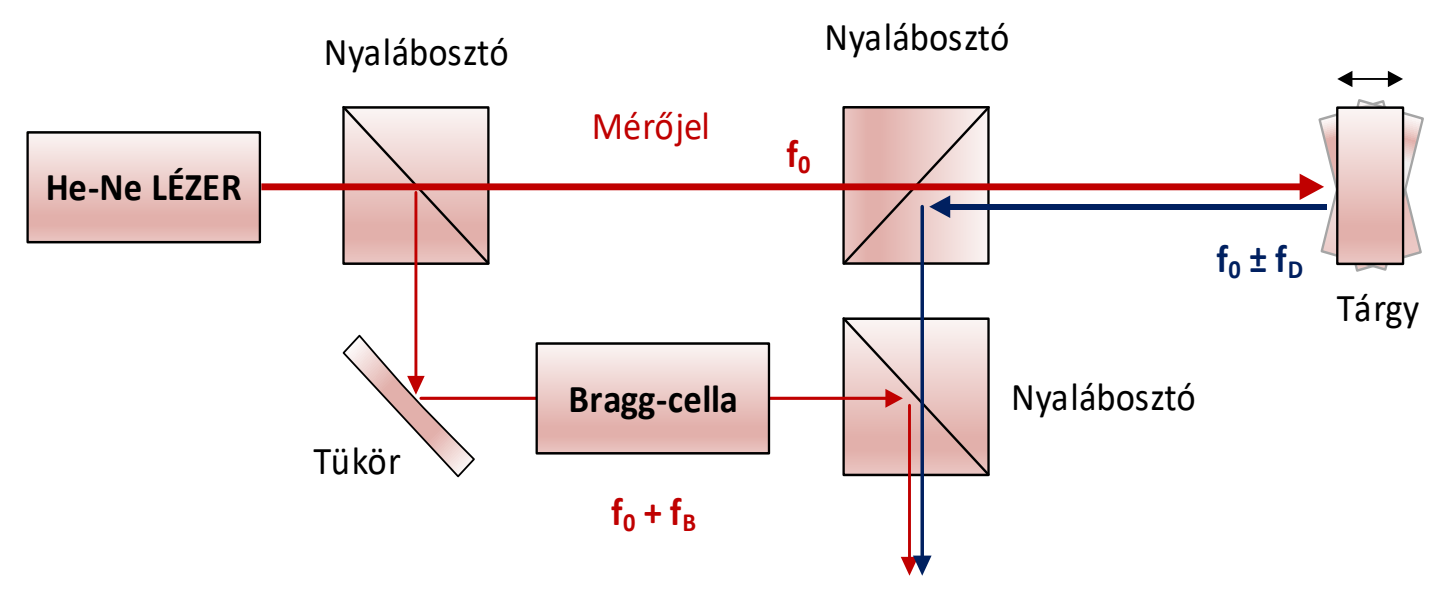

1. ábra. Az LDV optikai jelfeldolgozása 
Természetesen csak akkor igaz a fenti eredmény, ha a lézersugár és a sebességvektor párhuzamos. A fotodetektor kimenete egy immár frekvencia-modulált (FM) jel a Bragg-cella vivőfrekvenciájával és a Doppler-frekvenciával, mint modulációs frekvenciával. Az általunk alkalmazott LDV berendezés egy Polytec PDV-100 (Portable Digital Vibrometer) vibrométer .

\section{Mérési körülmények}

Méréseinket egy DMG CPX Alpha500 CNC esztergán végeztük a Miskolci Egyetem Szerszámgépészeti és Mechatronikai Intézet Szerszámgépek Tanszéke (SZGT) mühelyében. Mivel a fúrás közbeni rezgésmérés során a fúró állt, miközben a munkadarab forgott, így ezeket méréseket is álló fúrón végezhettük. Az LDV-vel a fúrószár megadott pontjának transzlációs rezgéseit mértük, a szerszámgépen kívülről (2. ábra). A mérések során a tokmányba befogott fúrószárakat a lézersugár a befogott végüknél, a horony végétöl kb. $1 \mathrm{~cm}$-re érte el, hasonlóan a fúrás közbeni mérésekhez.

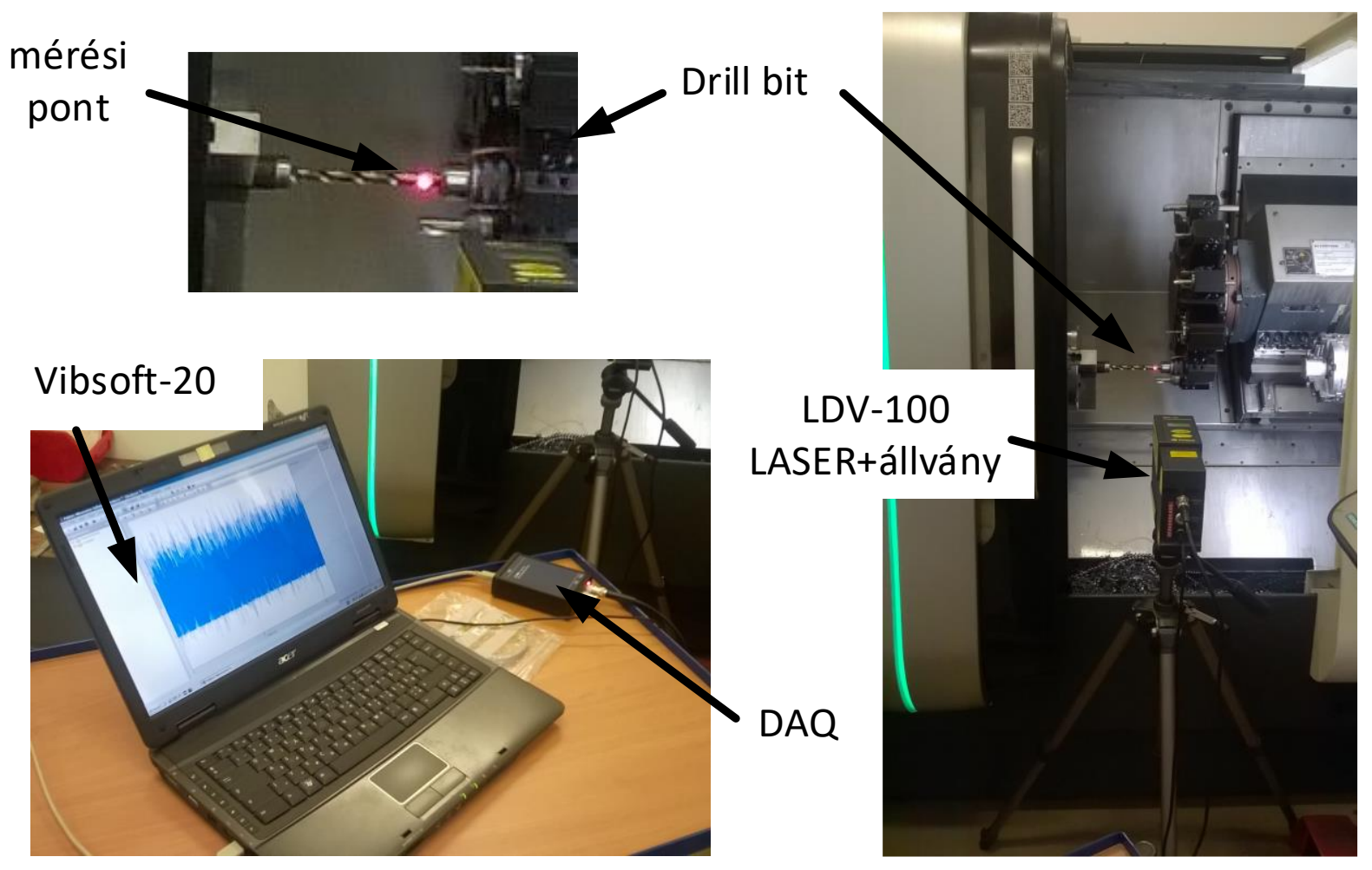

2. ábra. A mérés elrendezése

\section{Mérési eredmények}

Az impulzusgerjesztésre adott válaszok vizsgálatakor a fúrót először (tokmányba) mereven befogva koppintottuk meg. Ezután a fúró csúcsát nekitoltuk a munkadarabnak, s így gerjesztettük a szerszámot. A tompa ütés gumivégü fém ütővel, míg az éles ütés egy hengeres fémszár segítségével történt. 


\subsection{A fúró hegye szabad, a koppintás tompa}

A szabad rezgések méréséhez a fúrószárakat egy kis keresztirányú ütéssel, „koppintással” hoztuk rezgésbe, amely a másik végükhöz közel, attól kb. 1cm-re történt. Igyekeztünk mindig azonos erősséggel koppintani, de ennek erősségét nem tudtuk mérni. Mivel a lézersugár irányába eső mozgást mérjük, elsősorban az ilyen irányú (tehát párhuzamos) koppintás után várunk nagyobb amplitúdójú rezgést. Az első mérési sorozatban a fúrók másik vége (a hegye) teljesen szabad volt, és a koppintás gumikalapácscsal történt. A mérések többségében tisztán látszott, hogy a rezgéseket nem egy, hanem két közeli frekvencia jellemzi, amelyek szuperpozíciója lebegést eredményez (3. ábra).

A két rezgési módus amplitúdóinak nagysága a koppantás iránya mellett a fúrószár pozíciójától is függött. Ez utóbbi azt jelenti, hogy nem volt mindegy, hogy a horony vége és a lézerfolt a fúrószár ugyanazon oldalán volt-e ( $0^{\circ}$-os pozíció), vagy ehhez képest valamelyest elfordítva. Mi a $90^{\circ}$-os elfordítást preferáltuk.

a.)

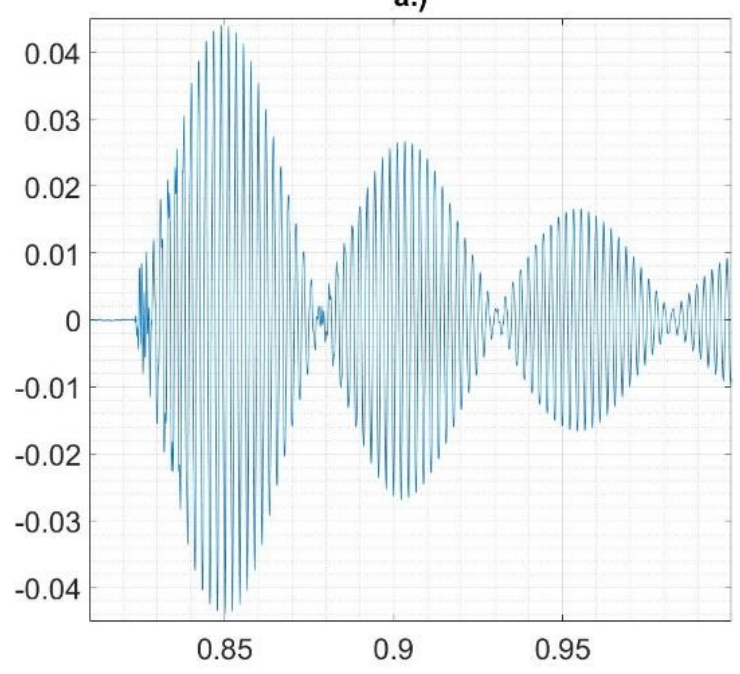

b.)

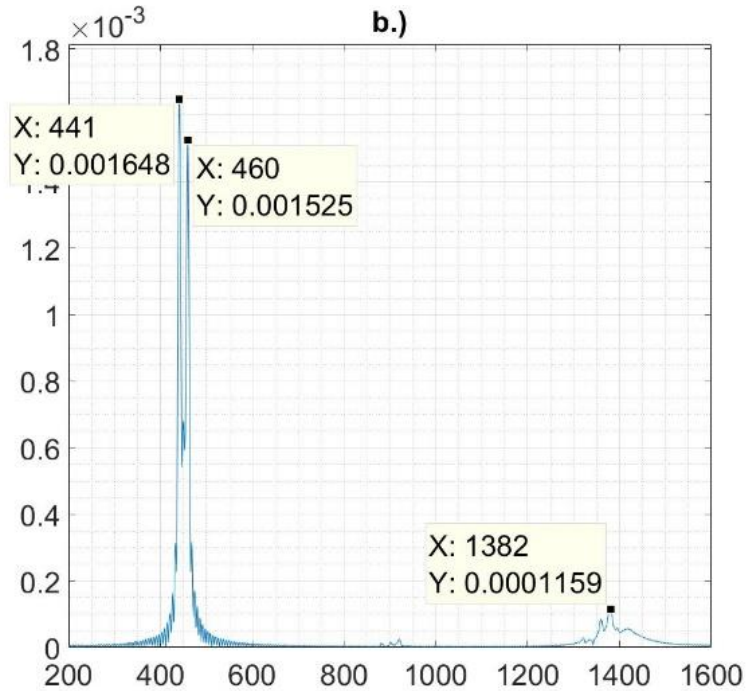

3. ábra. A tokmányba fogott $12 \mathrm{~mm}$ átméröjü fúrószár lézersugárra meröleges koppintás utáni rezgése: a.) idöspektrum (sebesség $[\mathrm{m} / \mathrm{s}]$ az idö függvényében); b.) FFT spektrum (amplitúdó a frekvencia függvényében)

A három fúró (a $9 \mathrm{~mm}$, a $10 \mathrm{~mm}$ és a $12 \mathrm{~mm}$ átmérőjủ fúró is) nagyon hasonló rezgési spektrumokat adott. Különbség volt viszont a módusok frekvenciáiban. A legvékonyabb fúrót $668( \pm 1)$ és $709( \pm 1) \mathrm{Hz}$, a közepeset $517( \pm 1)$ és $545( \pm 1) \mathrm{Hz}$, a legvastagabb fúrót $442( \pm 1)$ és $462( \pm 1) \mathrm{Hz}$-es módusok jellemzik (4. - 5. és 6. ábra). Az FFT spektrumok hasonlóságait az alábbiakban foglalhatjuk össze:

a) a lézersugárra merőleges koppintás esetén az FFT spektrumban mindkét frekvencia jól látszott, a lézersugár irányú koppintás esetén néha $\left(90^{\circ}\right.$-os pozícióban) csak az egyik,

b) a fúrószárak két különbözö pozíciójában (a $0^{\circ}$-os és a $90^{\circ}$-os) különbözö frekvenciák domináltak (kivéve a 10-es fúrót, ahol minden spektrumban a kisebb frekvencia dominált)

c) a lézersugár irányú koppintás esetén jelentősen megnövekedett a folytonos háttér is az FFT spektrumban. Később kiderült, hogy ennek az az oka, hogy a lézersugár irányú koppintás utáni első rezgések nagyon anharmonikusak, közelítőleg sem írhatók le harmonikus függvényekkel; 
d) a vastagabb fúrók esetében az alapfrekvencia háromszorosa környékén megjelent egy kisebb csúcs, ami nem a háttérzajtól származik (a háttérspektrum a 10. ábrán látható).
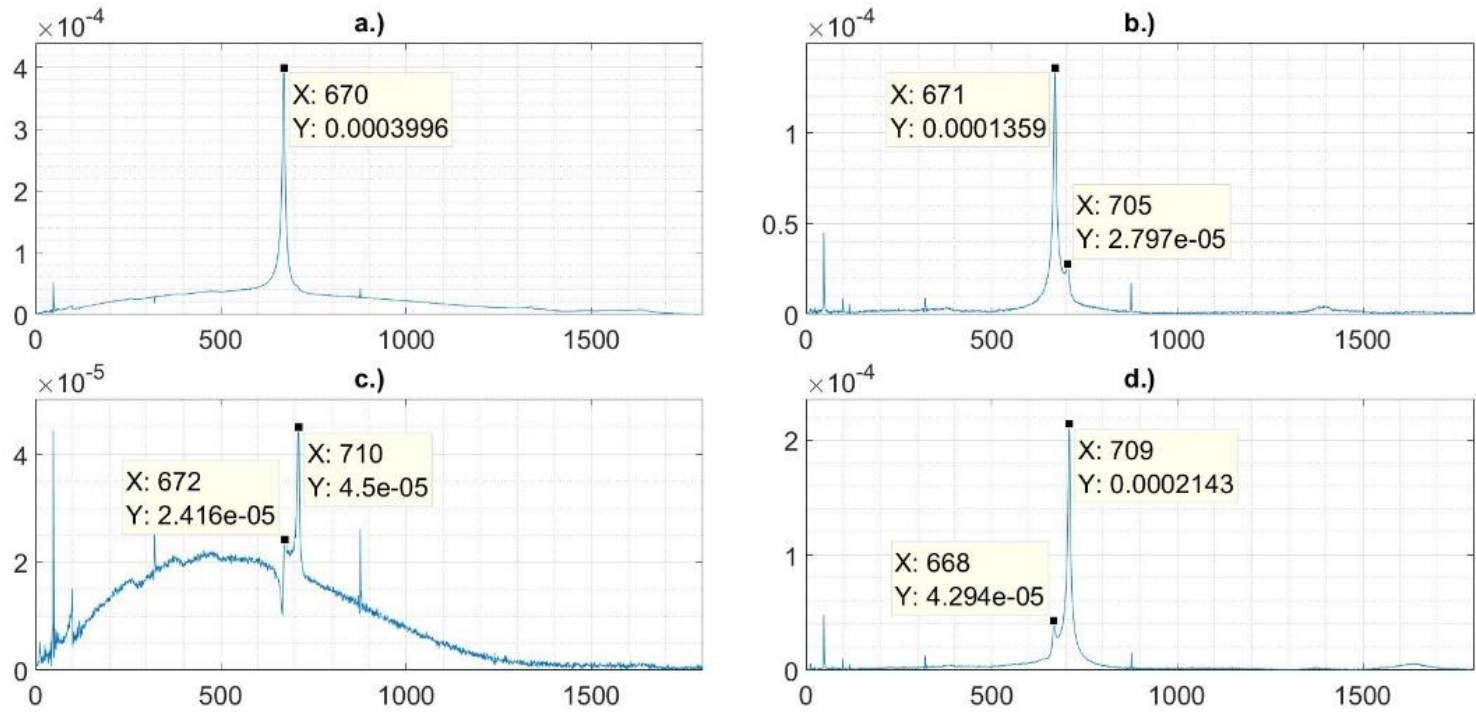

4. ábra. A tokmányba fogott 9 mm átméröjü fúrószár rezgési spektrumai (FFT) különbözö fúrószár pozíciókban és koppintási irányok esetén: a.) eredeti ( $0^{\circ}$-os) pozició, lézersugár irányú koppintás; b.) eredeti pozíció, lézersugárra meröleges koppintás; c.) 90-os pozíció, lézersugár irányú koppintás; d.) $90^{\circ}$-os pozició, lézersugárra meröleges koppintás
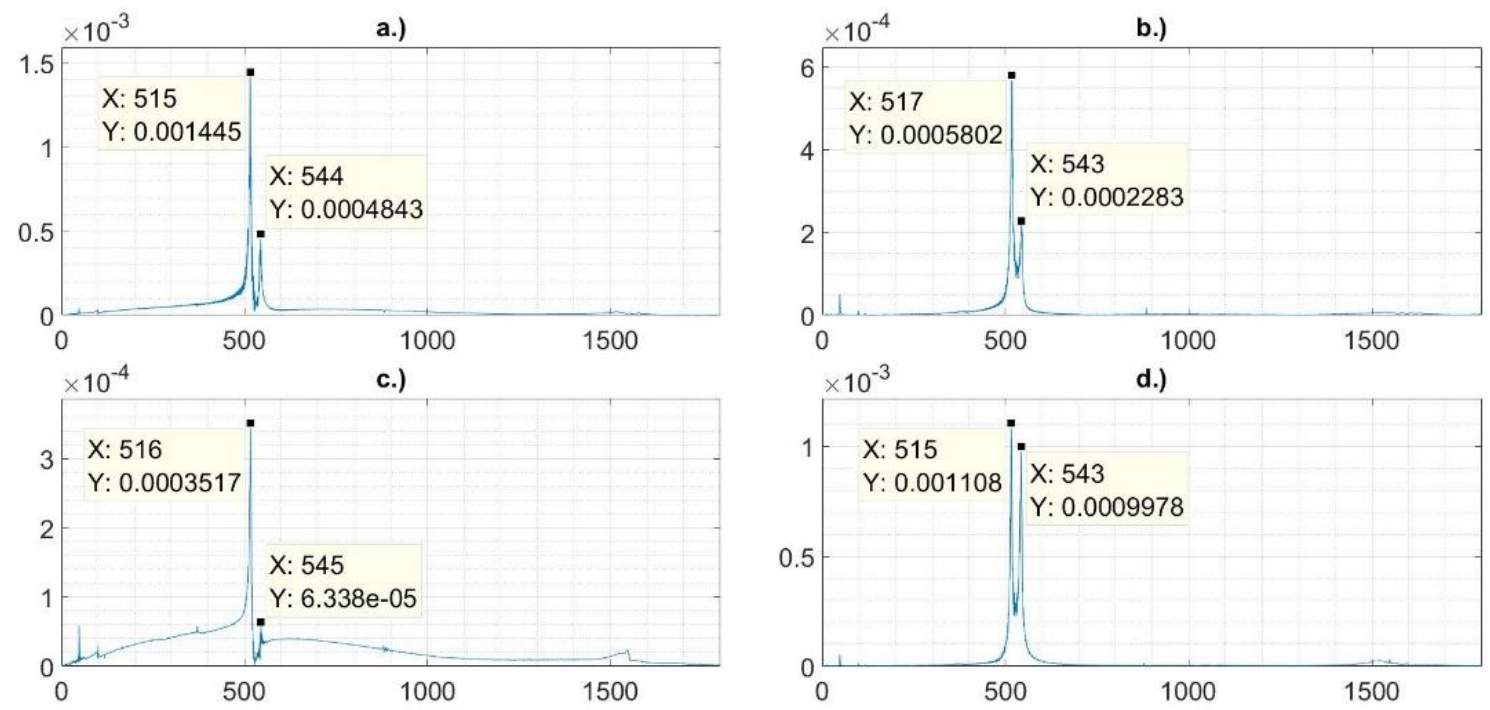

5. ábra. mint az elözö ábrán, de itt a fúrószár átmérője $10 \mathrm{~mm}$ 

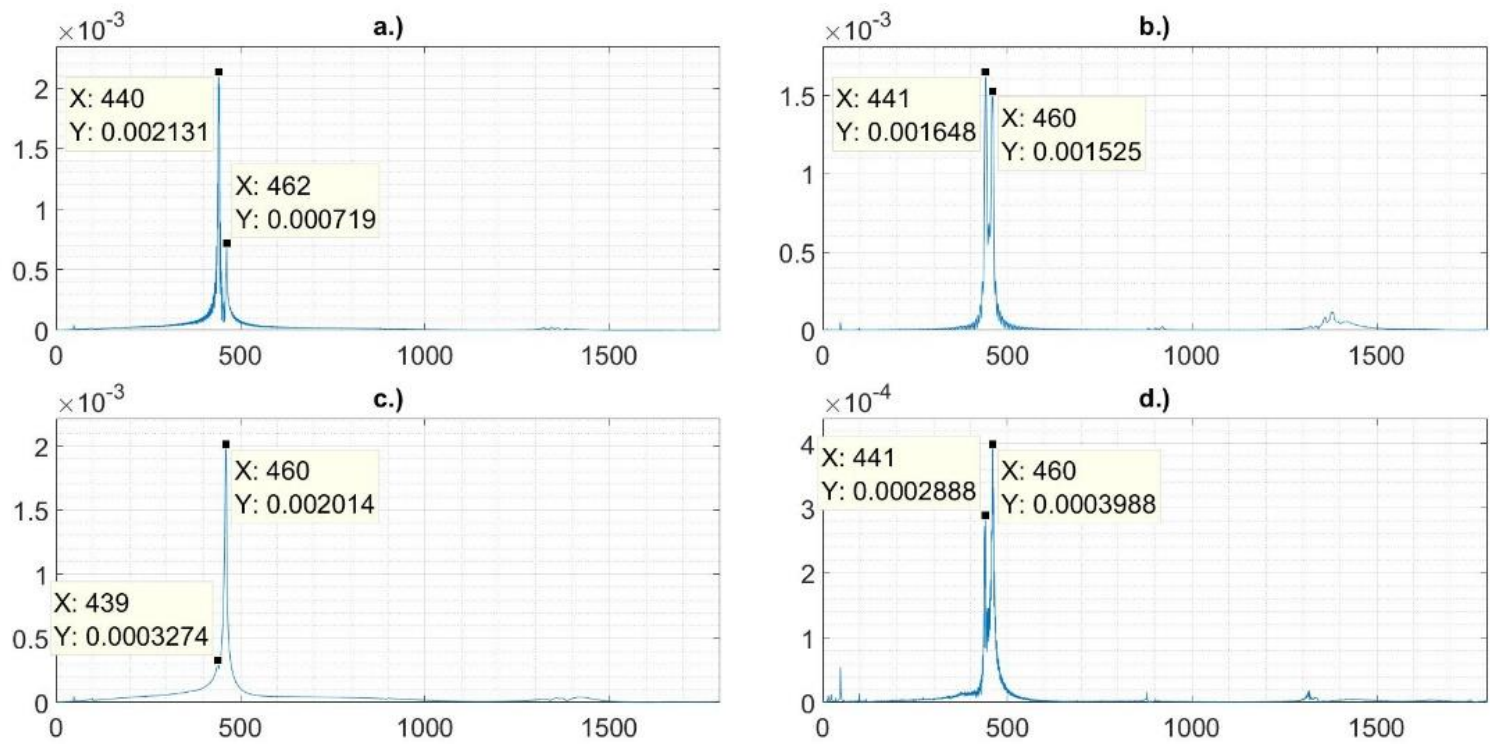

6. ábra. mint az elözö ábrán, de itt a fúrószár átmérője $12 \mathrm{~mm}$

\subsection{A fúró hegye a munkadarabhoz szorul}

Egy másik mérési sorozatban úgy vizsgáltuk meg a 9 mm-es fúró rezgéseit, hogy a fúró csúcsa sem volt szabad (a fúró a $90^{\circ}$-os pozícióban állt), azaz ,pontszerü” módon meg volt fogva. Ezt úgy értük el, hogy nekitoltuk a fúrót egy álló munkadarabnak. Először éppen csak nekikoccantottuk, később nagyobb erövel toltuk neki (a fúrón még $+0,04 \mathrm{~mm}$-t toltunk). Tapasztalataink szerint (7. ábra) a feszítő erő megváltoztatása alig volt hatással a rezgési spektrumra. Minden spektrumban domináns volt viszont egy kb. $100 \mathrm{~Hz}$ szélességü (FWHM), kb. 1405Hz középfrekvenciájú rezgési módus. Jelentősen befolyásolta azonban a rezgési spektrumot a pendítés iránya. A lézersugár irányú pendítés igen magas, középen kipúposodó folytonos hátteret eredményezett az $1 \mathrm{kHz}$ alatti tartományban. Ez a háttér a meröleges pendítés esetén szinte teljesen hiányzott.

Megvizsgáltuk, hogy a 7/a és c ábrákon (lézersugár irányú pendítés) miért olyan magas a folytonos háttér az $1 \mathrm{kHz}$ alatti tartományban. A 8/a ábrán a 7/c ábrán bemutatott FFT spektrumhoz tartozó időspektrumot láthatjuk. Ez a pendítés pillanatában hirtelen indul egy erősen anharmonikus szakasszal. Ha ezt kivesszük az FFT kiértékelésből, akkor eltünik a folytonos háttér nagy része is (7/b ábra).

Tehát az FFT spektrumok folytonos háttere egyértelmüen az első egy-két erősen anharmonikus periódus következménye. Nemcsak a 7/a és c ábrákon igaz ez, hanem a többi a) és c) ábrán is, ahol a koppintás lézersugár irányú. A szabad hegyü fúrószár rezgései azonban lassabban csengenek le, így az első egy-két erősen anharmonikus periódus hatása a teljes lecsengési szakaszra számított FFT spektrumra kisebb lesz. A lézersugárra merőleges koppintás esetén a lézerrel mért (tehát lézersugár irányú) rezgések lassan alakulnak ki (3/a ábra), így az elején erősen anharmonikus periódusokat nem tartalmaznak, és így hiányzik az FFT spektrumok folytonos háttere is. 

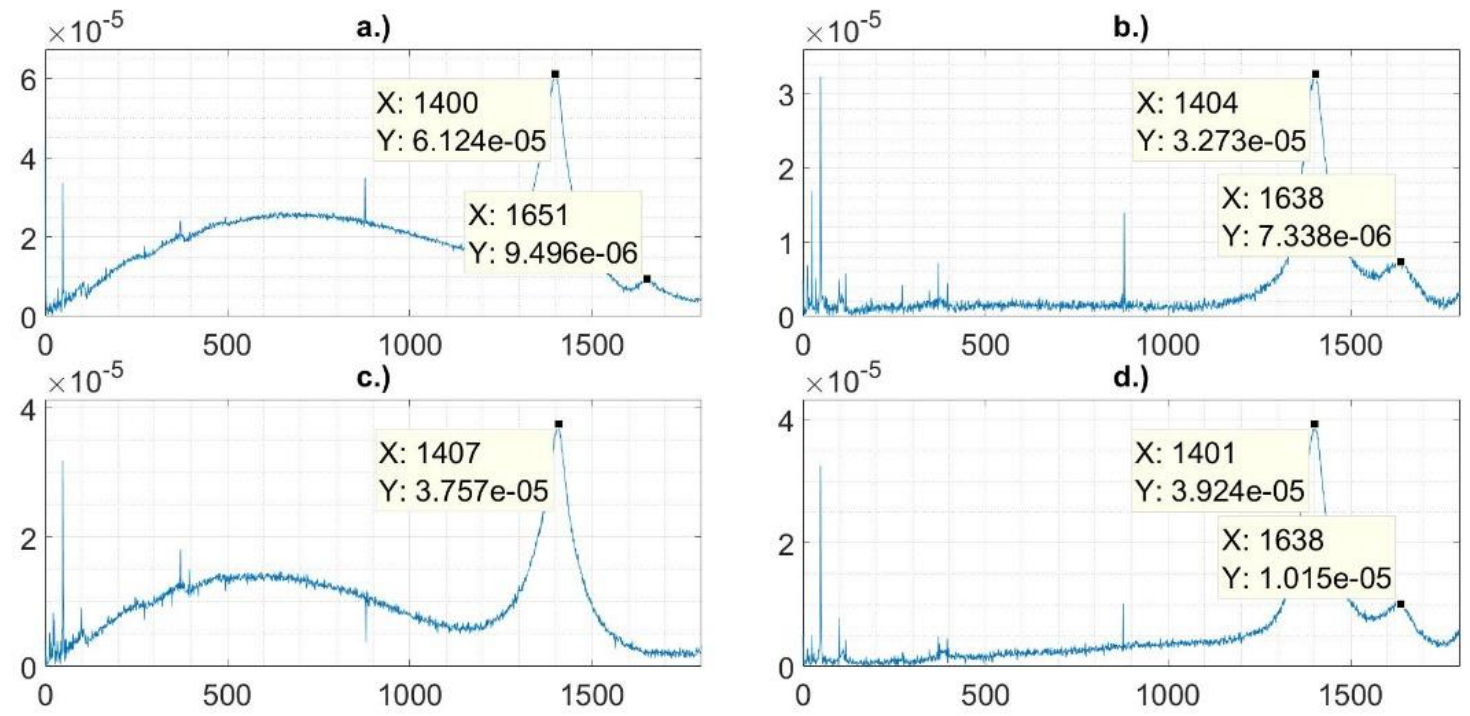

7. ábra. A tokmányba fogott 10mm átméröjü fúrószár rezgési spektrumai (FFT) úgy, hogy a fúró csúcsát ,,pontszerü" módon megfogtuk: a.) megfogás „,normál” erövel, lézersugár irányú koppintás; b.) megfogás „,normál” erővel, lézersugárra meröleges koppintás; c.) megfogás megnövelt erővel, lézersugár irányú koppintás; d.) megfogás megnövelt erövel, lézersugárra merőleges koppintás

a.)

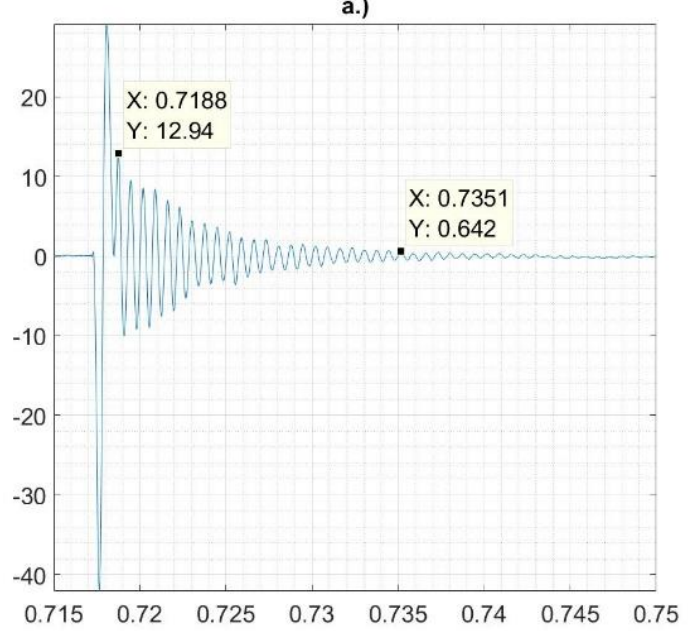

b.)

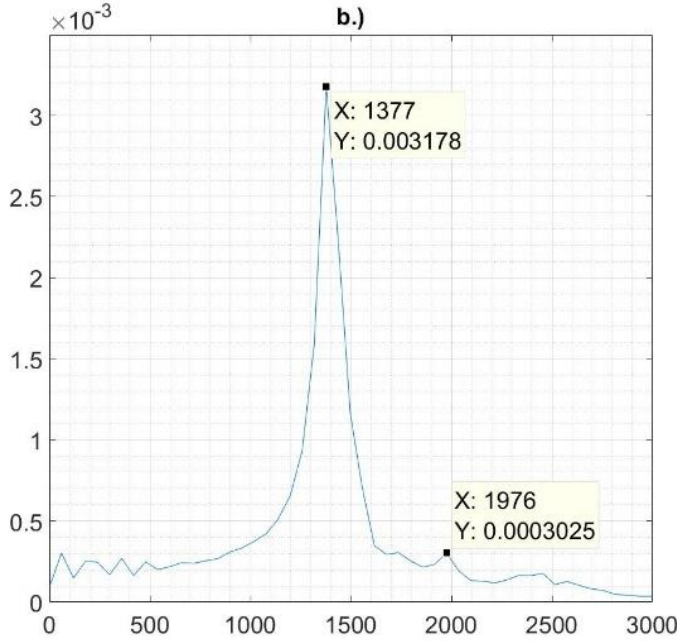

8. ábra. A 7/c ábrán bemutatott FFT spektrumhoz tartozó időspektrum (sebesség [ $\mathrm{m} / \mathrm{s}$ ] az idö függvényében) és a megjelölt két pont közötti rész FFT spektruma

\subsection{Szabad hegyü fúró éles koppintása}

Az előző fejezetekben a fúrószárat tompa koppintással hoztuk rezgésbe. A gyakorlatban ez egy gumikalapáccsal történő ütést jelentett, ami a fúrószár alaprezgéseit generálta. A fúrás közben azonban a fúrót más fémekkel történő érintkezés hozza rezgésbe, indokolt tehát az ilyen típusú rezgések vizsgálata is. 
A 9. ábrán azt mutatjuk be, hogy egy másik fúrószárral történő (éles) koppintás (b) milyen komplex frekvencia spektrumot eredményez a gumikalapáccsal történő (tompa) koppintás után mért (a) egyszerü spektrumhoz képest.

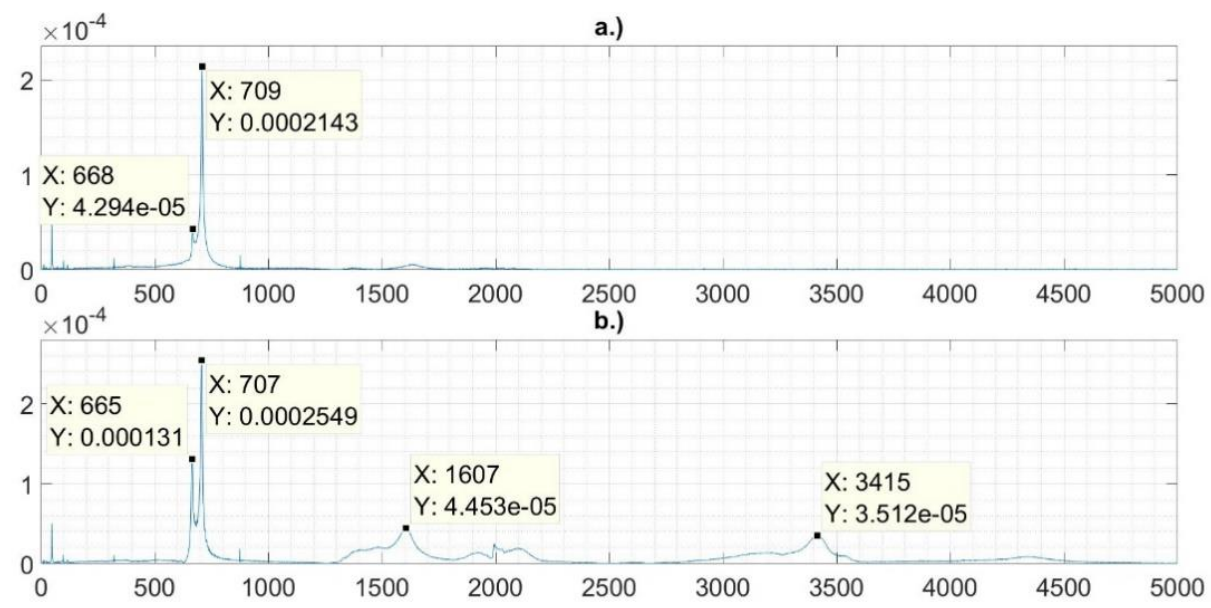

9. ábra. A 9mm átméröjü tokmányba fogott $90^{\circ}$-os pozíciójú fúrószár (lézersugárra merőleges koppintás) rezgési spektrumai (FFT: a.) gumikalapáccsal; b.) másik fúrószárral történö koppintást követöen

\subsection{Kiegészítő mérések}

A vastagabb fúró esetén megmértük, hogy milyen hatása van a rezgési spektrumra annak, hogy ha a fúrót a tokmányból 3mm-rel kintebb húzzuk. Ez a fúró tokmányon kívüli hosszát kb. 2,5\%-kal növeli meg $\left(l^{\prime}=1,025 l\right)$. A 10. ábrából látható, hogy a kihúzás a rezgési frekvenciákat 10-11Hz-cel csökkenti, ami kb. 2,5\% csökkenést jelent. Ennek az értelmezésére az 5. fejezetben még visszatérünk.
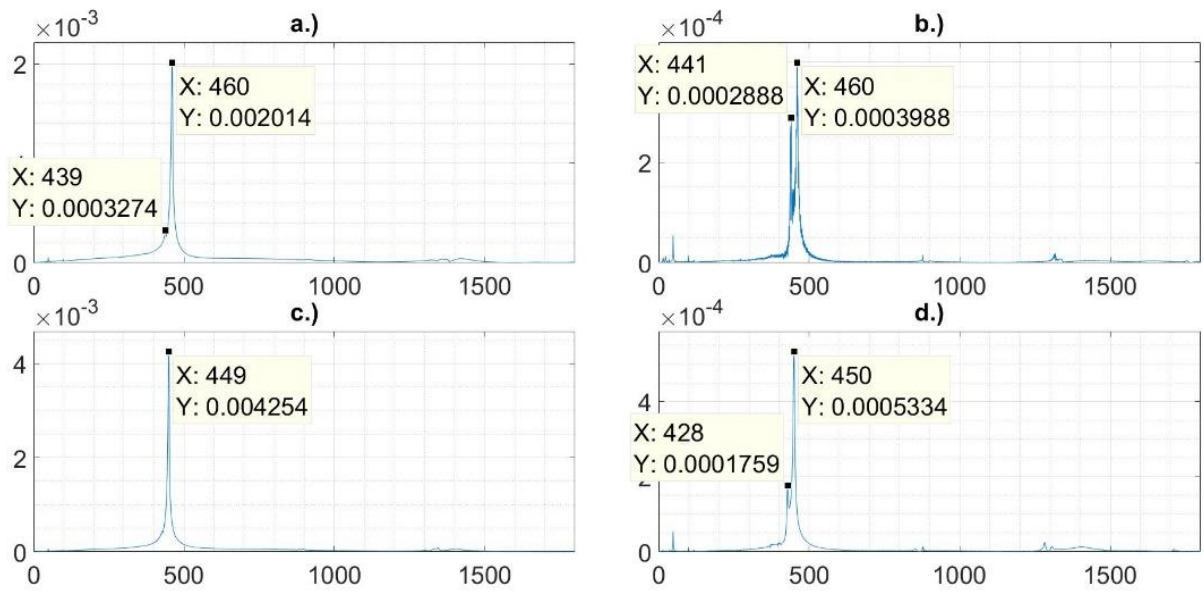

10. ábra. A 9mm átméröjü tokmányba fogott $90^{\circ}$-os poziciójú fúrószár rezgési spektrumai (FFT) az eredeti (a tokmányba teljesen betolt), ill. 3mm-rel kihúzott állapotában: a.) eredeti állapot, lézersugár irányú koppintás; b.) eredeti állapot, lézersugárra meröleges koppintás; c.) kihúzott állapot, lézersugár irányú koppintás; d.) kihúzott állapot, lézersugárra meröleges koppintás 
Az eddigi időspektrumok és FFT spektrumok a fúrószár minden rezgését mutatták, nemcsak azokat, amelyeket a koppintás okozott. Tapasztalataink szerint a fúrószárnak a szabad rezgések lecsengése után is maradnak rezgései (11. ábra). Ezeket az állandósult rezgéseket különböző környezeti hatások, elsősorban a mühelyben folyamatosan bekapcsolva tartott elektromos berendezések gerjesztik. Ezek közül a viszonylag zajos kompresszort emeljük ki $(48 \mathrm{~Hz}, 876 \mathrm{~Hz})$. Amikor minden fogyasztót kikapcsoltunk, a háttér teljesen fehérré vált, az FFT spektrum azonosítható frekvenciákat nem tartalmazott. A háttérspektrum több vonala azonosítható a korábban bemutatott FFT spektrumokban. Különösen igaz ez a 7. ábrára, ahol a megtámasztott csúcsú fúró kis amplitúdójú rezgései nem tudták a hátteret teljesen elnyomni.
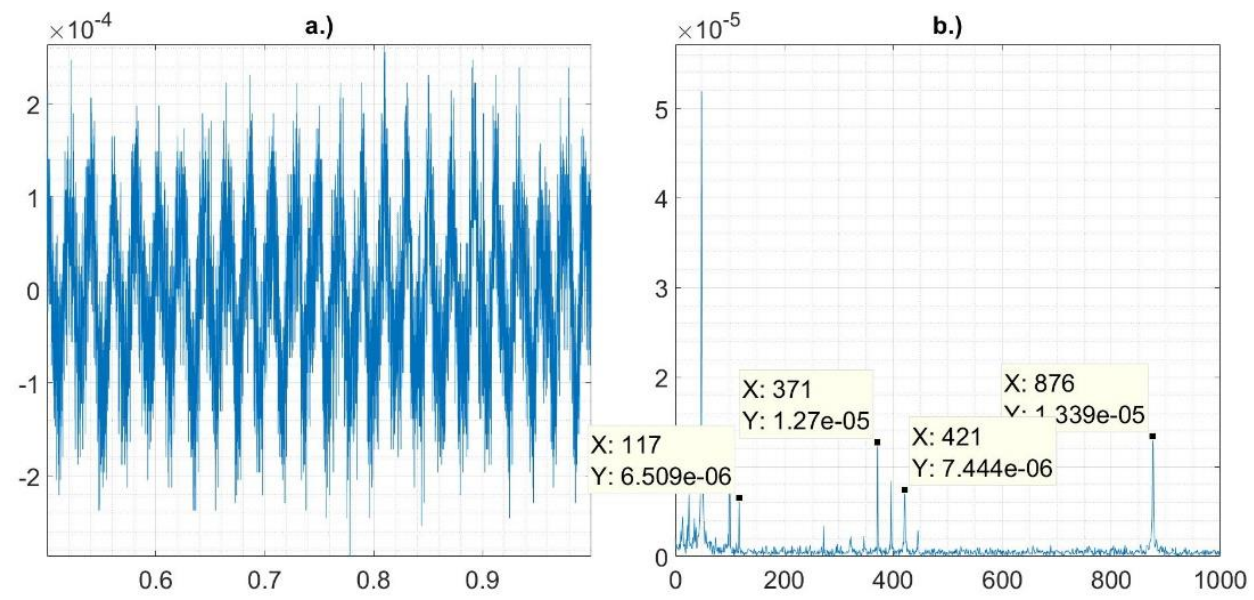

11. ábra. A háttér rezgések idöspektruma (sebesség $[\mathrm{m} / \mathrm{s}]$ az idö függvényében) és FFT spektruma.

\section{A befogott fúrószárak rezgéseinek leírása}

\subsection{Az egy oldalon befogott hengeres rudak rezgésének egyszerü modellje}

A fúrószárak rezgési frekvenciáinak pontos levezetése - a fúrószárak bonyolult geometriája miatt - reménytelen feladatnak tünik. Ehelyett tekintsünk egy tokmányba fogott kör keresztmetszetü hengeres rudat, amelynek a méretei egyeznek a fúró befoglaló méretével. A vékonyabb fúrót tehát egy $d=9 \mathrm{~mm}$ átmérőjü $l=94 \mathrm{~mm}$ hosszú (a fúró tokmányból kiálló hossza) egyik végén befogott húrnak tekintettük. Tudjuk, hogy ha a tömeg nélküli húr végére egy $m$ tömeget rögzítünk, akkor a kialakuló rezgés körferekvenciája:

$$
\omega=\sqrt{D / m},
$$

ahol $D$ a húr „rúgóállandója”. A mi esetünkben a tömeg nem koncentrált, hanem a húr mentén van elosztva, hisz az magának a húrnak a tömege. Közelítésként vegyük úgy, hogy az a húr közepére koncentrált, azaz lényegében egy $l / 2$ hosszú húrt tekintsünk!

Az irodalomból (Hack et al., 1988) ismert, hogy az egyik végén befogott húr lehajlása: 


$$
s=\frac{1}{3 E} \times \frac{l^{3}}{I} F, \text { ahol } \quad I_{k \ddot{r} r}=\frac{\pi}{4} R^{4}
$$

és F az alkalmazott erő. Kifejezve az erőt

$$
F=\frac{3 E \pi R^{4}}{4 l^{3}} s \quad \text { amibőla"rugóállandó" } \quad D=\frac{3 E \pi R^{4}}{4 l^{3}} .
$$

$\mathrm{Az}$ acél rugalmassági modulusát $\mathrm{E}=2 \cdot 10^{11} \mathrm{~Pa}$ értéknek véve a megadott adatokkal $D=1,86 \cdot 10^{6} \mathrm{~N} / \mathrm{m}$ adódik. Az acél sürüségét $7800 \mathrm{~kg} / \mathrm{m}^{3}$-nek véve a húr tömegére pedig $m=0,0466 \mathrm{~kg}$ adódik. (A fúró tokmányból kilógó része a horony miatt ennél kisebb tömegü, de mi most a modellünket tekintjük.) Mindezekkel a körfrekvenciára $\omega=63151 / \mathrm{s}$, a frekvenciára pedig $f=1005 \mathrm{~Hz}$ adódik. Ez kb 50\%-kal meghaladja a kísérletileg talált $668 \mathrm{~Hz}$ és $709 \mathrm{~Hz}$ értékeket. Ezen a ponton még nem volt világos, hogy az eltérés a hengeres rúd rossz modellezése, vagy a hengeres rúd és a fúró (,,hornyozás” miatti) különbözőségének tulajdonítható-e inkább. A ,hornyozás” hatása nyilvánvalóan ilyen irányú, mert a fúróban a horony jobban csökkenti a $D$ értékét (az $\mathrm{R}^{4}$ függés miatt - lásd (6)), mint a tömeget (ami $\mathrm{R}^{2}$-tel arányos). Tehát a modellre számított frekvenciának biztosan nagyobbnak kellett adódnia, mint a fúró rezgésének tényleges frekvenciái.

A legvastagabb fúró adatai: $l=121 \mathrm{~mm}, d=12 \mathrm{~mm}$. Ezekkel az adatokkal (változatlan rugalmassági modulust és sürüséget feltételezve) a $D$ értéke 1,482-szeresére, a tömeg 2,288-szörösére adódik, tehát csupán a modell pálcák geometriai adatai miatt is csökkennie kell a frekvenciának bő 19,5\%-kal. Ha a közepes fúró adatait $(l=104 \mathrm{~mm}, d=10 \mathrm{~mm})$ tekintjük, akkor pedig 9,3\%-kal kisebb frekvenciát várunk, mint a legvékonyabb fúró esetében.

\subsection{A hangvilla modellje}

Az irodalomban találtunk valóságos tömegeloszlású hangvilla modell elméleti leírását is. Ez az elmélet henger alakú villaágak esetére (Han at al., 1999; Tuning fork, 2021):

$$
\omega=\frac{1,875^{2} R}{2 l^{2}} \sqrt{E / \rho} .
$$

Az előző pontban leírt egyszerüsített modell alapján is kifejezhetjük hasonló alakban a körfrekvenciát. Ehhez a (4) egyenletbe be kell írni a (6) egyenletből a D-t (figyelembe véve, hogy itt $l$ helyébe $l / 2$ írandó) és be kell írni a tömeget $(m=R 2 \pi \cdot l \cdot \rho)$ is a teljes 1-lel:

$$
\omega=\sqrt{D / m}=\sqrt{24 E R^{2} / 4 l^{4} \rho}=\frac{\sqrt{6} R}{l^{2}} \sqrt{E / \rho} .
$$

A (7) eredmény a (8)-nál 28,2\%-kal kisebb, azaz $\omega(7)=0,718 \omega(8)$. Vagyis az egyszerü modellünkben használt koncentrált tömeg kb. 40\%-kal nagyobb $(\omega(8)=1,393 \omega(7))$ frekvenciákra vezet, mint a homogén tömegeloszlásból levezetett érték. A hangvilla modellel a (7) egyenlet alapján a legvékonyabb fúrónak megfelelő hengeres hangvilla ágakra számított frekvencia $722 \mathrm{~Hz}$ lesz, ami még közelebb van a kísérletileg talált $668 \mathrm{~Hz}$ és $709 \mathrm{~Hz}$ értékekhez. Azt gondoljuk, hogy ez a pár százalékos eltérés már tényleg csak a „hornyozás” következménye lehet. Ahogy fentebb is írtuk, a hornyozásnak mindenképpen csökkentenie kell a hengeres rúd rezgési frekvenciáját. A másik két fúróra a hangvilla modell $655 \mathrm{~Hz}$ $(d=10 \mathrm{~mm})$, illetve $581 \mathrm{~Hz}(d=12 \mathrm{~mm})$ sajátfrekvencia értékeket ad. 


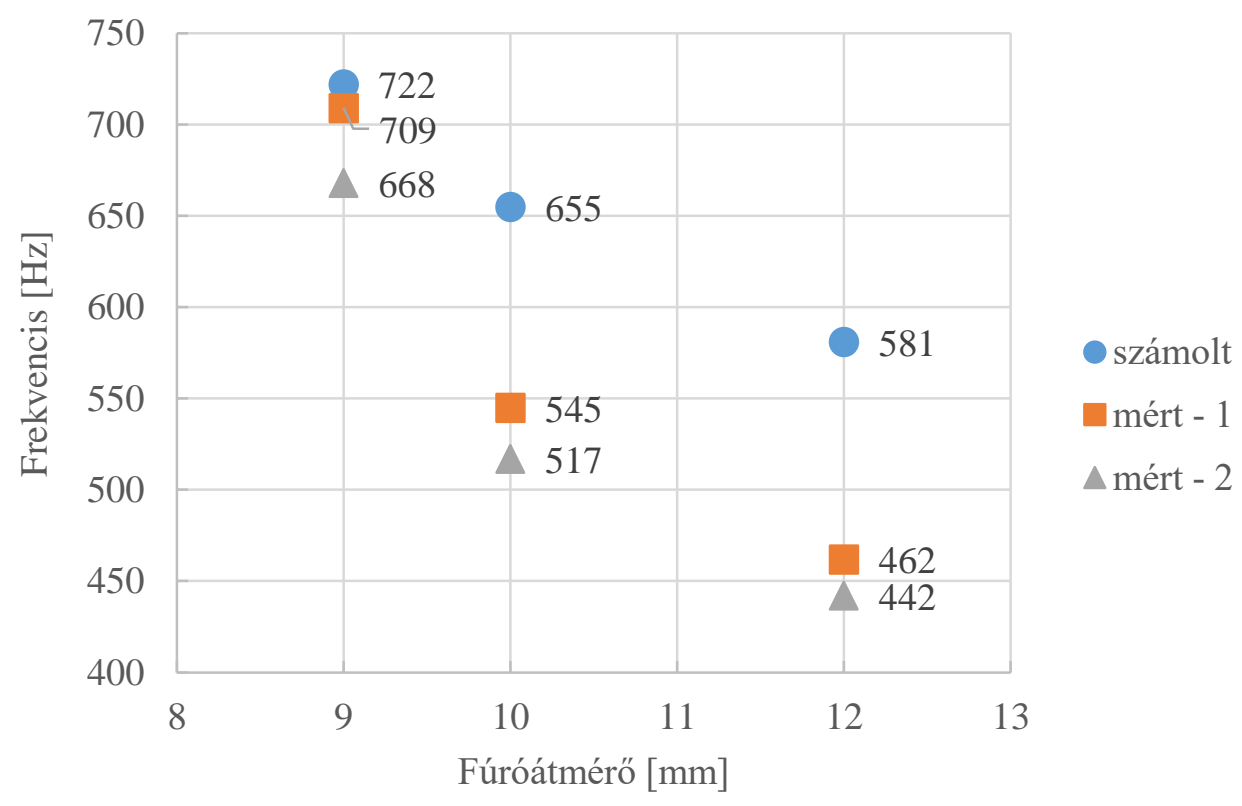

12. ábra. A fúrószárak mért rezgési frekvenciáinak összevetése az egyezö méretü hengeres rudak számitott frekvenciáival (növekvö frekvencia szerint a $12 \mathrm{~mm}$, a $10 \mathrm{~mm}$ és a $9 \mathrm{~mm}$ átméröjü fúrószárak)

Ha ezeket a számított frekvencia értékeket összevetjük a fúrószár rezgések mért frekvenciáival (12. ábra), akkor láthatjuk, hogy az eltérés erős függvénye a fúrószár átméröjének. A nagyobb mért frekvencia érték a $9 \mathrm{~mm}$-es fúró esetén csak kb. 2\%-kal van a hengeres rúdra számítottnak. Viszont a 10mm-es fúró esetén az eltérés már 16,8\%-os, a $12 \mathrm{~mm}$-es fúró esetén pedig 20,5\%-os. Ezt a tendenciát minden bizonnyal az okozza, hogy a horony méretei (mélysége és szélessége is) relatíve gyorsabban nőnek, mint a fúrószár átmérője. Tehát a vastagabb fúróból relatíve is több anyag van kimarva, mint a vékonyabból.

Megjegyezzük, hogy a befogott hengeres rúd egyszerü modelljére levezetett (8) képlet akkor egyezne a hangvillára érvényes (7) képlettel, ha az előbbiben $l$ helyére $l$ '=1,180l-t írnánk. Ez azt jelenti - mivel a modellünkben a koncentrált tömeget középre, azaz a $0,5 l$ pozícióba tettük - hogy a $0,59 l$ pozícióba tett koncentrált tömeggel adódik ki hangvillára levezetett képlet.

A 10. ábrán láttuk, hogy milyen hatása van a rezgési spektrumra annak, hogy ha a fúrót a tokmányból-rel kintebb húzzuk, azaz a fúró tokmányon kívüli hosszát kb. 2,5\%-kal megnöveljük $\left(l^{\prime}=1,025 l\right)$. Láttuk, hogy a kihúzás a rezgési frekvenciákat $10-11 \mathrm{~Hz}$-cel csökkenti, ami kb. 2,5\% csökkenést jelent. A (7) és (8) egyenletek szerint az $1 / l^{2}$-es függés miatt a modell alapján azonban kb. 5\%-os frekvencia csökkenést várnánk. A különbség minden bizonnyal abból adódik, hogy a kihúzással nem csupán a fúrószár hosszát, hanem ezen belül a fúrószárnak a horony nélküli hosszát is megnöveltük. Vagyis egy picit közelítettük a fúrószárat a hengeres rúd modellhez, aminek viszont kb. 10\%-kal nagyobb a rezgési frekvenciája. Tehát az 5\%-os csökkenés felét a modellhez való közeledés kompenzálhatta.

Az egy oldalon befogott hengeres rudak rezgésének első felharmonikusát úgy kapjuk, hogy a (7) képletben az $1,875^{2}$ helyett 4,692-et írunk [8,9]. Ez azt jelenti, hogy a felharmonikus frekvencia az alapfrekvencia 6,26-szorosa. Ez a 9mm-es fúró estében 4,18kHz és 4,44kHz felharmonikus (mért) frekvenciákat jelent. A 9/b ábrán ezen a környéken látunk is egy kisebb csúcsot. Mindazonáltal az ábrán látható többi, az alapmódus fölötti frekvencia hengeres rúd rezgésként való értelmezése nem lehetséges. Ezek 
nem csupán a hornyozástól, hanem a fúrószár befogás módjától is függenek. A 13. ábrán azt mutatjuk be, hogy a különböző tokmányok - ugyanazt a fúrót ugyanolyan körülmények között mérve - hogyan befolyásolják a rezgési spektrumot. Látható, hogy a tokmány típusa pár százalék erejéig hatással van az alapfrekvenciákra is. A hajtott tokmány - ugyanolyan fúrókilógás mellett - rövidebb szabad fúrószárat jelent, azaz vélhetően hosszabban vagy „kintebb” fogja meg a fúrószárat. A magasabb frekvenciájú komponensek azonban teljesen különböznek, bár a fenti modellekben szereplö adatokban nem történt változás.
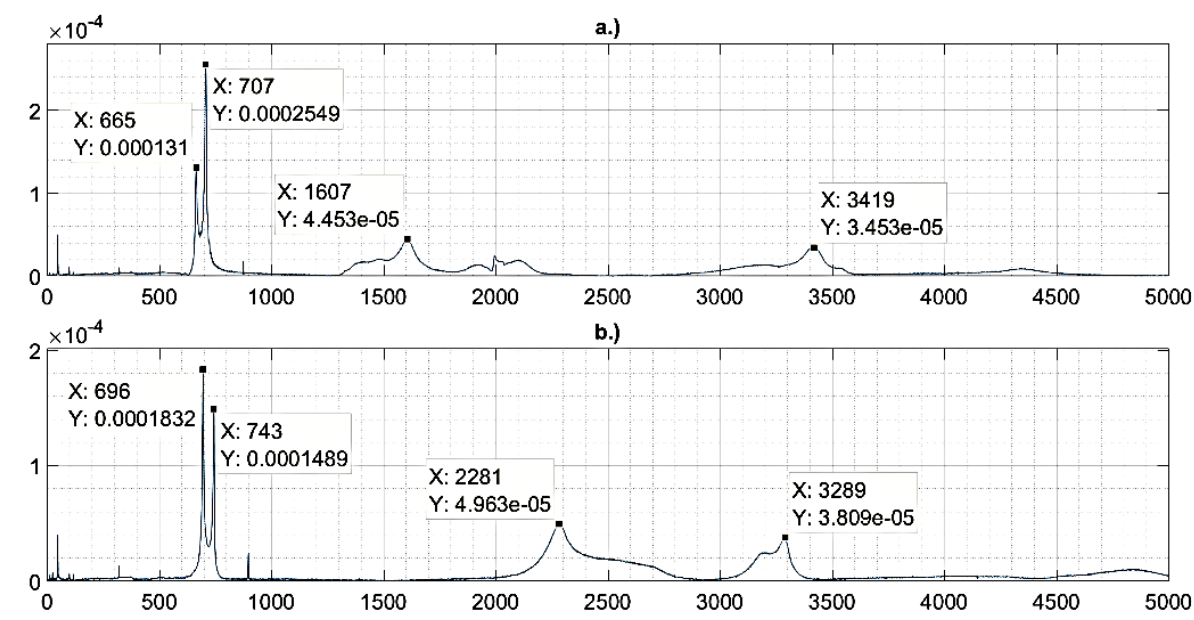

13. ábra. A 9mm átmérőjü, rögzitett és „, hajtott” típusú tokmányba fogott fúrószár (lézersugárra meröleges fémes koppintás) rezgési spektrumai (FFT): a.) 3-pofás tokmányba fogott, rögzített fúró, b.) hajtott, befogóperselyes tokmányba fogott fúró

\subsection{A befogott és a fúrószár csúcsánál megtámasztott fúrószár modellezése}

Amikor a befogott fúró csúcsát nekitoltuk az álló munkadarabnak, akkor azt a véget pontszerü módon fogtuk meg. Ez a helyzet leginkább az egyik végén befogott, a másik végén csuklósan megfogott rúddal modellezhető. Nyilvánvaló, hogy a megtámasztás és a csuklós megfogás nem pontosan ugyanazt jelenti, de talán nincs közte nagy különbség. Különösen, ha figyelembe vesszük, hogy a támasztáskor alkalmazott erőnek nem volt hatása a rezgési spektrumra.

A különbözöképpen befogott egyenletes tömegeloszlású rudak rezgései analitikusan is tárgyalhatók (Bosznay, 1962). Az egyik végén befogott, a másik szabad szabályos hengeres rudak rezgéseire a (Tyihonov \& Szamarszkij, 1956) irodalomban megadott képlet a (7) képlettel azonos alakra hozható. (Valójában a 1,875² helyett $1,87^{2}$ áll, de ez minden bizonnyal csak kerekítési eltérés.) Az egyik végén befogott, a másik végén csuklósan megfogott hengeres rúd rezgéseit leíró képletben fellépő együttható értéke a (Bosznay, 1962) irodalom szerint 3,92², ami a szabad végü rúdhoz képest 4,37-szer nagyobb frekvenciát eredményezne. A mérések viszont csak 2,73-szor (=1405/515) adtak nagyobb frekvenciát. Egészen pontosan a 10mm-es fúrószár befoglaló adatainak megfelelő egyenletes tömegeloszlású egyik végén befogott, a másik végén csuklósan megfogott hengeres rúd számított sajátfrekvenciája $2570 \mathrm{~Hz}$, míg a fúrószár mért sajátfrekvenciája csak $1405 \mathrm{~Hz}$. Ez a nagy eltérés is minden bizonnyal a hornyozás következménye. 


\section{6. Összefoglalás, következtetések}

Megállapítottuk, hogy a tokmányba fogott és megpendített fúrószárak keresztirányú szabad rezgéseit általában két, egymáshoz közeli (néhány \%-on belüli) frekvenciájú komponens szuperpozíciójából származó lebegés dominálja, amelyek a fúrószárak horonyvég irányú és az arra merőleges keresztirányú rezgéséhez tartoznak. Ez főleg a fúrószár lézersugárra merőleges koppintás utáni rezgése esetén igaz, ekkor a rezgések harmonikusak. Lézersugár irányú koppintás esetén az első rezgések erősen anharmonikusak.

A fúrószárakat egyik végén befogott kör keresztmetszetü hengeres rudaknak tekintve modelleztük a rezgéseket. A hangvilla modell a 9mm átmérőjü fúrószár szabad rezgéseinek frekvenciáit pár százalékon belüli pontossággal megadja, a vastagabb (10 és $12 \mathrm{~mm}$-es) fúrószárak esetében viszont $15-20 \%$-kal felülbecsli. Ennek az oka miden bizonnyal a vastagabb fúrók (relatív értelemben is) nagyobb horony mérete.

A fúróvég megtámasztása (amit úgy értük el, hogy nekitoltuk a fúrót egy álló munkadarabnak) a rezgési frekvenciát kb. 2,7-szeresére növelte, szemben a hengeres rudakra elméletileg levezetett 4,37szeres értékkel. A fúrószár tokmányból kintebb húzása csökkentette a rezgési frekvenciákat kb. olyan arányban, ahogy a fúró tokmányon kívüli hossza növekedett.

A koppintás típusa is jelentős hatással volt a rezgési spektrumra. A tompa koppintás (gumikalapács) eredményezte a fentebb tárgyalt alapfrekvenciákat. Az éles koppintás (másik fúrószárral) számos további magasabb frekvenciájú rezgést is eredményezett, amelyeket a hengeres rúd modellel nem tudtunk értelmezni.

\section{Köszönetnyilvánítás}

A szerzők köszönetüket fejezik ki a Miskolci Egyetem Szerszámgépészeti és Mechatronikai Intézet Szerszámgépek Intézeti Tanszékének, hogy mühelyében lehetőséget biztosított a cikkben szereplő kísérletek elvégzéséhez. Külön köszönet illeti Máté Bálintot, aki a kísérletek lebonyolításában, a szerszámgép kezelésében sok segítséget nyújtott.

Ezen a helyen kíván köszönetet mondani Béres Miklós az NKFI-125117 számú projekt Nemzeti Kutatási Fejlesztési és Innovációs Alapból biztosított támogatásának, melynek révén a kísérletek a K_17 pályázati program finanszírozásában valósultak meg.

\section{Irodalom}

[1] Béres, M., Paripás, B.: Fúrószár rezgéseinek mérése lézer Doppler módszerrel, 2017 Multiscience - XXXI. microCAD International Multidisciplinary Scientific Conference, C2: Natural Sciences, ISBN 978-963-358--132-2, University of Miskolc (C2/4)

[2] Béres, M., Paripás, B. (2018). Measurement of vibration by laser Doppler method in the course of drilling. In K. Jármai, B. Bolló (Eds.), Series Title: Lect. Notes Mechanical Engineering, Book Title: Vehicle and Automotive Engineering 2, Book Subtitle: Proceedings of the 2nd VAE2018, (pp. 199-208). Miskolc, Hungary, ISBN: 978-3-319-75676-9, Springer https://doi.org/10.1007/978-3-319-75677-6_16

[3] Béres, M., Paripás, B. (2018). Measuring of drill bit vibration by laser Doppler methods. IOP $\begin{array}{llll}\text { Conf. Series: Materials Science and } & \end{array}$ https://doi.org/10.1088/1757-899X/448/1/012068 
[4] Béres, M., Paripás, B. (2017). Comparison of two laser interferometric methods for the study of vibrations. In Jármai K., Bolló B. (Eds.), Vehicle and Automotive Engineering. Lecture Notes in Mechanical Engineering. Springer, Cham. https://doi.org/10.1007/978-3-319-51189-4_20

[5] Polytec GmbH: PDV-100 Portable Digital Vibrometer Datasheet, 2012

[6] Hack, F., Kugler, S., Radnai, Gy., Tóth, G. (1988). Négyjegyü függvénytáblázatok. Matematikai, fizikai, kémiai összefüggések. Tankönyvkiadó, Budapest, ISBN 9631808440

[7] https://en.wikipedia.org/wiki/Tuning_fork

[8] Han, S. M., Benaroya, H., Wei, T. (1999). Dynamics of transversely vibrating beams using four engineering theories. Journal of Sound and Vibration, 225(5), 935-988. https://doi.org/10.1006/jsvi.1999.2257

[9] Bosznay, Á. (1962). Müszaki rezgéstan. Müszaki Könyvkiadó, Budapest

[10] Tyihonov, A. N., Szamarszkij, A. A. (1956). A matematikai fizika differenciálegyenletei. Akadémiai kiadó, Budapest 